\title{
QoS AND MOBILE TECHNOLOGIES
}

EDITORS:

AISHA-HASSAN ABDALLA HASHIM

OMER MAHMOUD

RASHEED SAEED

DEPARTMENT OF ELECTRICAL AND COMPUTER ENGINEERING

INTERNATIONAL ISLAMIC UNIVERSITY MALAYSIA

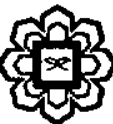

IIUM Press 


\title{
Published by: \\ IIUM Press \\ International Islamic University Malaysia
}

First Edition, 2011

OIIUM Press, IIUM

\begin{abstract}
All rights reserved. No part of this publication may be reproduced, stored in a retrieval system, or transmitted, in any form or by any means, electronic, mechanical, photocopying, recording, or otherwise, without any prior written permission of the publisher.
\end{abstract}

Perpustakaan Negara Malaysia C Cataloguing-in-Publication Data

ISBN: $978-967-418-142-0$

Member of Majlis Penerbitan IImiah Malaysia - MAPIM

(Malaysian Scholarly Publishing Council)

Printed by :

IIUM PRINTING SDN.BHD.

No. 1, Jalan Industri Batu ( aves 1/3

Taman Perindustrian Batu Caves

Batu Caves Centre Point 68100 Batu Caves

Selangor Darul Fhsan

Tel: +603-6188 1542 / 44/45 Fax +603-6188 1543

EMAIL: iiumprinting(a yahoo.com 


\section{TABLE OF CONTENTS}

TITLE

No

PART 1:QOS APPROACHES

CHAPTER 1: Introduction to QoS Approaches 2

CHAPTER 2: Internet Quality Of Service Architectures 11

CHAPTER 3: Integrated Services 17

CHAPTER 4: Differentiated Services 21

CHAPTER 5: $\quad$ Quality Of Service (QoS) Ad-Hoc On-Demand Distance Vector 27 (AODV)

CHAPTER 6: QoS Routing In Ad-H loc Wireless Networks 33

CHAPTER 7: MPLS And Traffic Engineering 41

\section{PART 2: MOBILITY MANAGEMENT APPROACHES}

CHAPTER 8: Introduction to Mobility Management 47

CHAPTER 9: Nested Mobile Networks 53

CHAPTER 10: Evaluation of NEMO Extensions 59

CHAPTER 11: Ilandoff Process In Micromobility Protocols 65

CHAPTER 12: Comparison Between Network Simulators 71

PART 3: WIRELESS TECHNOLOGY

CHAPTER 13: Introduction to Local Area Network (LAN) Communication 77

CHAPTER 14: MANET routing protocols $\quad 85$

CHAPTER 15: VANET Applications 95

CHAPTER 16: Vehicle To Vehicle Routing Protocols 101

CHAPTER 17: Wi-Fi Mesh Network 111

CHAPTER 18: Overview Of Wimax Mesh $\quad 117$

CHAPTER 19: Current Trends On WIMAX Using MIMO Technology 129

CHAPTER 20: Self-Organized Femtocell Networks 141

CHAPTER 21: Self-Organized Synchronization For Femtocell Network $\quad 155$

CHAPTER 22: $\quad$ Spectrum Management In Fentocell 169

CHAPTER 23: Smart Grid Communication $\quad 179$

CHAPTER 24: UWB Overview 189

CHAPTER 25: ZIGBEE Applications $\quad 197$ 
CHAPTER 26: Improvement Of Vertical Handover In GPRS/WIFI Seamless 205 Convergence

CHAPTER 27: The Application Of Sensor Network And Routing Protocols In 215 Wireless Communication

CHAPTER 28: A Study Of Channel Assignment Approach To Reduce Frequent Reassignment

CHAPTER 29: Association Management Schemes For Wireless Mesh Network 231

CHAPTER 30: Challenges In Multi-Radio Multi-Channel Wireless Mesh 237 Network

CHAPTER 31: Mobility Support in Diffserv and MPLS network 243

CHAPTER 32: Mobility Management And Context Transfer 247

CHAPTER 33: LTE-Advanced Overview 251

CHAPTER 34: Time Synchronization Protocols And Approaches 261

CHAPTER 35: $\quad$ MPLS Architectures 265 


\title{
CHAPTER 4
}

\section{DIFFERENTIATED SERVICES}

\author{
SULAIMAN SYED AND, AISHA HASSAN ABDALLA HASHIM AND MUHAMMAD A. \\ F. MUDATHIR
}

ECE Dept. Fac. of Eng., International Islamic Univ. Malaysia (IUUM). Jalan Gombak. 53100 Kuala Lumpur. Malaysia.

\subsection{INTRODUCTION}

Differentiated Services was developed to reach a scalable QoS for the intemet. It divides traffic into groups of predefined forwarding treatment. These groups are called forwarding classes. Each packet contains a Differentiated Services Code Point (DSCP) which states what class it belongs. The differentiated services architecture is based on a simple model where traffic entering a network is classified and possibly conditioned at the boundaries of the network, and its DSCP assigned. Within the core of the network, packets are forwarded according to the Per-Hop Behaviour (PHB) associated with the DSCP.

\subsection{DIFFSERV STANDARDS}

Resources are allocated to classes rather than specific flows. A flow's QoS requirements are provided by prioritization and provisioning [1]. Edge routers handle the classification of packets and interior routers just follow the corresponding forwarding treatment per hop behaviour (PHB) to a packet's class. Ingress routcrs ensure that the traffic entering the DS domain conforms to any Traffic Conditioning Agreements (TCA) between it and the other domain to which the ingress node is connected. Egress routers, on the other hand, perform traffic conditioning functions on traffic forwarded to a neighbouring domain, depending on the details of the TCA between the two domains. A boundary router acts as both Ingress and Egress router as shown in Fig. 4.1.

No end-to-end services are defined by DiffServ, rather, forwarding treatments are. DiffServ basically comprises forwarding treatments and admission control. Monitors flow packets rather than reserves required resources. Resources are allocated to forwarding classes and the amount of traffic for each class is monitored. Provisioning and prioritization give different levels of services.

Service Level Agreements (SLA) between ISP and customers are implemented by the boundary nodes connecting customer to ISP. SLAs are contracts with different rates for different service levels.

Different domain service providers could map their definitions through interdomain agreements. DiffServ can be deployed and expanded in the intemet. 